\title{
Evaluation of the Efficacy of Selected Herbicides on Weed Biomass Control and Maize [Zea mays (L.)] Yield Production in Two Agro-ecological Zones in Swaziland
}

\author{
Thandwa Menzi Dlamini, Henry Raphael Mloza-Banda, Oghenetsavbuko Todo Edje \\ Department of Crop Production, Faculty of Agriculture and Consumer Sciences, University of Swaziland, Luyengo Campus, Swaziland
}

Email address:

tmdlamini@uniswa.sz (T. M. Dlamini), thandwaim@gmail.com (T. M. Dlamini)

\section{To cite this article:}

Thandwa Menzi Dlamini, Henry Raphael Mloza-Banda, Oghenetsavbuko Todo Edje. Evaluation of the Efficacy of Selected Herbicides on Weed Biomass Control and Maize [Zea mays (L.)] Yield Production in Two Agro-ecological Zones in Swaziland. American Journal of Agriculture and Forestry. Vol. 4, No. 4, 2016, pp. 75-85. doi: 10.11648/j.ajaf.20160404.12

Received: June 7, 2016; Accepted: June 16, 2016; Published: July 18, 2016

\begin{abstract}
Maize is the most important food crop in Swaziland, and is produced by over $90 \%$ of smallholder farmers on Swazi Nation Land. Excluding environmental variables, yield losses in maize are caused mainly by competition from weeds. Herbicidal weed control is a promising way to control weeds at initial stages of crop growth with the appropriate choice and rate of herbicides. An experiment was conducted at the Malkerns Research Station and Mangcongco experimental site during the 2014/2015 cropping season. The main objective of the study was to evaluate the efficacy of available herbicides for weed control and maize grain yield. There were 16 treatments; Four herbicides were used; Bladex Plus, Gardomil Gold, Lumax and 2,4-D Amine 480. Four rates of application were used; Control (hand-weeding), rate of recommendation based on the \% clay content in the soil, half and full the rate recommended by the local retailers. A randomised complete block design (RCBD) experiment in a factorial arrangement, replicated four times was used. Highest efficacy of broadleaves in Malkerns was $97 \%$ when the herbicide Lumax at the rate recommended as per \% clay content in the soil and in Mangcongco it was $76 \%$ with the use of herbicide Gardomil Gold at the full rate recommended by retailers. Weed control efficiencies for grasses in both sites at all rates were negative. Gardomil Gold was efficient in controlling sedges in both sites, at the full rate of the retailer's recommendation $(60 \%)$ in Malkerns and at half the rate recommended by retailers $(28 \%)$ in Mangcongco. In Malkerns the highest grain yield was $8741 \mathrm{~kg} / \mathrm{ha}$ with the treatment 2,4-D Amine 480 at the full rate recommended by retailers. In Mangcongco, the highest grain yield was $4427 \mathrm{~kg} /$ ha with the treatment Bladex Plus at the rate recommended based on \% clay content in the soil. The highest grain yield in Malkerns was $8741 \mathrm{~kg} / \mathrm{ha}$ when 2,4-D Amine 480 was used, at full rate recommended by retailer's ( $2 \mathrm{~L} / \mathrm{ha})$. While in Mangcongco, Bladex Plus, at the rate based on the \% clay content in the soil $(4.3$ $\mathrm{L} / \mathrm{ha}$ ) had the highest yield of $4427 \mathrm{~kg} / \mathrm{ha}$. Hence herbicides and rates with higher yields are recommended for each site.
\end{abstract}

Keywords: Herbicides, Efficacy, Bladex Plus, Gardomil Gold, Lumax, 2,4-D Amine 480, \% Clay Content

\section{Introduction}

Maize (Zea mays L.) is the most important food crop in Swaziland, and is produced by over $90 \%$ of smallholder farmers on Swazi Nation Land (SNL) [17]. Maize is used as a measure of food security in Swaziland [6].

While almost all households in SNL produce maize, the country has not reached self-sufficient levels in maize production since the 1980s [4]. Erratic weather conditions, lack of inputs, limited use of fertiliser and capacity to utilize new technologies (herbicide use), sets limit to the overall maize produced in the country. Maize production has, in recent years declined. During the 2013/2014 cropping season, maize produced in Swaziland was 86000 tonnes while the country needed 130000 tonnes, a shortfall of $33 \%$ which was imported [20].

Excluding environmental variables, yield losses in maize are caused mainly by competition from weeds [23]. Common agronomic factors that contribute to weed problems are inadequate land preparation (soil tillage, soil levelling in lowland areas), inadequate water management, labour shortages for hand weeding, delayed and incorrect use of 
herbicide applications and non-use of weed competitive varieties [10]. Crop yield losses could be caused by increase in the weed biomass, weed density and weed species [33]. Weeds are one of the greatest limiting factors to efficient crop production. Severe weed infestation has been reported by [7], to reduce maize grain yield by as much as $50-100 \%$.

Weeds interfere with crops by increasing competition (for light, water and nutrients) and/or allelopathy [8]. They harbour insect and disease pests as well. Weeds interfere with agronomic operations such as fertiliser application and harvesting [28]. Weeds may also lead to higher cost in agricultural production. Smallholder farmers spend $50-70 \%$ of their total farm labour budget on weed control which is mostly by hoe-weeding [9]. In most farming communities, weeding is not done on time because labour is often very scarce during the early stages when control is essential. Late weeding results in crop losses, especially if it is done after the critical period of weed competition [7]. In Swaziland farmers spend more time in controlling weeds than on any other aspect of crop production. As a result, some farmers are using herbicides to control weeds in their fields and this method of weed control is effective and efficient under the prevailing circumstances. However, the limited choice of herbicides available in the country and lack of knowledge on how to use herbicides correctly is a big challenge for many farmers [25]. Among the limited number of registered herbicides in Swaziland, post-emergence herbicides are preferred and are applied during the early stages of crop growth.

Herbicidal weed control seems to be a promising way to control weeds at initial stages of crop growth. Selection of proper herbicides and application rates is essential for successful weed management in all crop production systems [12].

The main objective of the study was to evaluate the efficacy of four available herbicides and the optimum rate of application for yield improvements in maize production in Swaziland.

\section{Materials and Methods}

\subsection{Experimental Sites}

The experiment was conducted during the 2014/2015 cropping season in two agro-ecological zones of Swaziland; the upper Middleveld and the Highveld at Malkerns Research Station and Mangcongco Experimental Farm respectively. The Malkerns Research Station is located at $26.34^{\circ} \mathrm{S}$, $31.10^{\circ} \mathrm{E}$, and is $750 \mathrm{~m}$ above sea level. The mean annual rainfall range is $800-1,000 \mathrm{~mm}$ and the mean annual temperature is $18^{\circ} \mathrm{C}$. The dark loam to sandy loam soil on the Malkerns Research Station is classified as an Oxisol of the Malkerns soil series (M-set). Mangcongco is located at $26^{\circ} 34^{\prime} 59^{\prime \prime} \mathrm{S}, 30^{\circ} 59^{\prime} 49^{\prime \prime} \mathrm{E}$ and has an average altitude of 1500 $\mathrm{m}$ above sea level. Mean annual temperatures are cool $\left(16^{\circ} \mathrm{C}\right)$ and annual rainfall about $1500 \mathrm{~mm}$. The soils in Mangcongco characterised as ruston clay loam classified as ferralitic.

\subsection{Experimental Procedures}

There were 16 treatments as shown on Table 1.

Table 1. Description of treatments.

\begin{tabular}{|c|c|c|c|c|}
\hline Treatment code & Herbicides & Rates of application & Malkerns & Mangcongco \\
\hline 1 & No herbicide & Control $0 \mathrm{~L} / \mathrm{ha}$ (hand-weeding) & $0 \mathrm{~L} / \mathrm{ha}$ & $0 \mathrm{~L} / \mathrm{ha}$ \\
\hline 2 & Bladex Plus & $\%$ clay recommended rate & $3.6 \mathrm{~L} / \mathrm{ha}$ & $2.9 \mathrm{~L} / \mathrm{ha}$ \\
\hline 3 & Bladex Plus & Retailers half rate & $2 \mathrm{~L} / \mathrm{ha}$ & $2 \mathrm{~L} / \mathrm{ha}$ \\
\hline 4 & Bladex Plus & Retailers full rate & $4 \mathrm{~L} / \mathrm{ha}$ & $4 \mathrm{~L} / \mathrm{ha}$ \\
\hline 5 & No herbicide & Control $0 \mathrm{~L} / \mathrm{ha}$ (hand-weeding) & $0 \mathrm{~L} / \mathrm{ha}$ & $0 \mathrm{~L} / \mathrm{ha}$ \\
\hline 6 & Gardomil Gold & $\%$ clay recommended rate & $3.2 \mathrm{~L} / \mathrm{ha}$ & $2.5 \mathrm{~L} / \mathrm{ha}$ \\
\hline 7 & Gardomil Gold & Retailers half rate & $1.6 \mathrm{~L} / \mathrm{ha}$ & $1.6 \mathrm{~L} / \mathrm{ha}$ \\
\hline 8 & Gardomil Gold & Retailers full rate & $3.2 \mathrm{~L} / \mathrm{ha}$ & $3.2 \mathrm{~L} / \mathrm{ha}$ \\
\hline 9 & No herbicide & Control $0 \mathrm{~L} / \mathrm{ha}$ (hand-weeding) & $0 \mathrm{~L} / \mathrm{ha}$ & $0 \mathrm{~L} / \mathrm{ha}$ \\
\hline 10 & Lumax & $\%$ clay recommended rate & $4 \mathrm{~L} / \mathrm{ha}$ & $3.6 \mathrm{~L} / \mathrm{ha}$ \\
\hline 11 & Lumax & Retailers half rate & $1 \mathrm{~L} / \mathrm{ha}$ & $1 \mathrm{~L} / \mathrm{ha}$ \\
\hline 12 & Lumax & Retailers full rate & $2 \mathrm{~L} / \mathrm{ha}$ & $2 \mathrm{~L} / \mathrm{ha}$ \\
\hline 13 & No herbicide & Control $0 \mathrm{~L} / \mathrm{ha}$ (hand-weeding) & $0 \mathrm{~L} / \mathrm{ha}$ & $0 \mathrm{~L} / \mathrm{ha}$ \\
\hline 14 & 2,4-D Amine 480 & $\%$ clay recommended rate & $4.3 \mathrm{~L} / \mathrm{ha}$ & $3.3 \mathrm{~L} / \mathrm{ha}$ \\
\hline 15 & 2,4-D Amine 480 & Retailers half rate & $1 \mathrm{~L} / \mathrm{ha}$ & $1 \mathrm{~L} / \mathrm{ha}$ \\
\hline 16 & 2,4-D Amine 480 & Retailers full rate & $2 \mathrm{~L} / \mathrm{ha}$ & $2 \mathrm{~L} / \mathrm{ha}$ \\
\hline
\end{tabular}

The experimental design was a randomised complete block design (RCBD) in a factorial arrangement, replicated four times in both sites. Plots with the dimensions of 5 metres long and 4.5 metres wide with a distance of 1 metre between plots were marked. Soil sampling was done and samples were analysed at the University of Swaziland Chemistry Laboratory for physio-chemical characteristics: Sand, Silt, Clay, pH, Organic matter. Maize variety SC 403 was planted at a spacing of $90 \mathrm{~cm}$ inter-row and $25 \mathrm{~cm}$ intra-row. Planting at the
Malkerns site was done on the $4^{\text {th }}$ November 2014 and for Mangcongco it was done on the $10^{\text {th }}$ November 2014. Basal fertiliser [N:P:K, 2:3:2 (22)] was applied two weeks after planting the maize at the rate of $400 \mathrm{~kg} / \mathrm{ha}$ for Malkerns and $500 \mathrm{~kg} / \mathrm{ha}$ in Mangcongco. Side dressing with LAN (28\% N), five weeks after planting at the rate of $100 \mathrm{~kg} / \mathrm{ha}$ and $115 \mathrm{~kg} / \mathrm{ha}$ for Malkerns and Mangcongco respectively. Herbicides were sprayed four weeks after planting, as per the treatments (Table 1), with a hand-pumped CP 3 knapsack sprayer which was 
calibrated to deliver $250 \mathrm{~L} / \mathrm{ha}$ at $210 \mathrm{kPa}$ using a floodjet nozzle.

\subsection{Data Collection}

\subsubsection{Data Collected on Weeds}

The evaluation of effectiveness of herbicides was performed 4 weeks after application. Basic parameters of infestation such as species composition, dry weight of weeds and weed control efficiency and labour rate of weeding and spraying were taken. Assessment of weed infestation was carried out before herbicide spray in all the treatments including control, using a visual determination of weed density and weed species distribution. Using a $0.5 \mathrm{~m} \times 0.5 \mathrm{~m}$ $\left(0.25 \mathrm{~m}^{2}\right)$ quadrat, weed density was scored on a rating scale of 1-6 on the soil within the quadrat. From the weed dry matter at 8, 12 and 16 WAP, weed control efficiency was then calculated as per the formula;

$$
\mathrm{WEC} \%=\frac{\mathrm{WDc}-\mathrm{WDt}}{\mathrm{WDc}} \times 100
$$

Where;

WCE -Weed control efficiency (per cent);

WDc - Weed dry weight $(\mathrm{g} / \mathrm{m}-2)$ in control plot;

WDt - Weed weight $(\mathrm{g} / \mathrm{m}-2)$ in treated plot;

\subsubsection{Data Collected on Maize}

Plant height was taken at three development stages of growth, at 8, 10 and 12 weeks after planting. The height of the maize plant was measured from the ground level to the leaf sheath of the last leaf of the plant, using a $5 \mathrm{~m}$ tape measure. LAI was calculated using the ratio of leaf area over ground area occupied by the five sampled plants, as shown in formula below:

$$
L A I=\frac{\text { Leaf area }\left(\mathrm{cm}^{2}\right)}{\text { Ground area }(90 \mathrm{~cm} \times 25 \mathrm{~cm} \times 5)}
$$

Labour cost was determined by calculating the amount of time taken to weed and to apply the herbicides for all the plots. Labour cost was counted in minutes per plot then expressed in man-days per hectare.

Dry mass of stems, leaves, unshelled cobs and tassels were determined after separating these parts from five sampled plants and oven drying them for 72 hours at $75^{\circ} \mathrm{C}$.

Seed yield was determined from net plot area and was calculated using the formula:

Seed Yield $=\frac{\text { Net plot fresh mass } \times \text { factor }(10) \times 100-\text { moisture content at harvesting }}{(100-\text { Desired moisture content }) \times \text { net plot area }\left(m^{2}\right)}$

\subsection{Statistical Analysis}

The data collected was subjected to statistical analysis. Analysis of variance (ANOVA) and correlation, for the data was carried out using (Genstat 5 statistical package, 1997). Significant differences between means were estimated by the Least Significant Difference at $5 \%$ and $1 \%$ level of significance depending on applicability.

\section{Results and Discussion}

\subsection{Meteorological Data}

Total rainfall in the cropping season 2014/2015 was higher in Mangcongco as compared to Malkerns; Mangcongco at $915.4 \mathrm{~mm}$ and Malkerns at $713.8 \mathrm{~mm}$. The highest rainfall was received in the month of December for both sites, with Mangcongco receiving $380.3 \mathrm{~mm}$ and Malkerns $297.0 \mathrm{~mm}$ (Figure 1). The high amount of rainfall is attributed to the hailstorms that were received in December, with Mangcongco having two hailstorms and Malkerns one. In March Mangcongco still received a lot of rainfall at $128.1 \mathrm{~mm}$ while Malkerns received $23.9 \mathrm{~mm}$. The excess moisture in Mangcongco might have caused leaching and run-off losses of herbicides. In water-logged soils weeds are more competitive than crop plants. Higher herbicide sorption occurs under a water deficit due to the fact that $\mathrm{H}+$ ions, with concentrations dependent on the soil moisture content, compete with the herbicide molecules for the sorption sites at the soil colloids' surface (Blanco et al., 2013). Other factors that might have attributed to less weed control efficacies in Mangcongco are excess rainfall received during the course of the experiment which resulted in waterlogged, flooded and saturated soils. Nitrogen issues seemed to have been another issue because of the saturation of the soil, hence, the nitrogen was subject to loss from leaching and/or denitrification. The mean minimum and maximum temperatures for Mangcongco and Malkerns were $17.2^{\circ} \mathrm{C}$ and $28.3^{\circ} \mathrm{C}$ respectively. Herbicide degradation rates generally increase with increased temperature and soil moisture because both chemical and microbial decomposition rates increase under conditions of higher temperature and moisture as observed for Malkens with higher temperatures compared to Mangcongco. Cool, dry conditions cause slow degradation, hence, greater carryover potential [19].

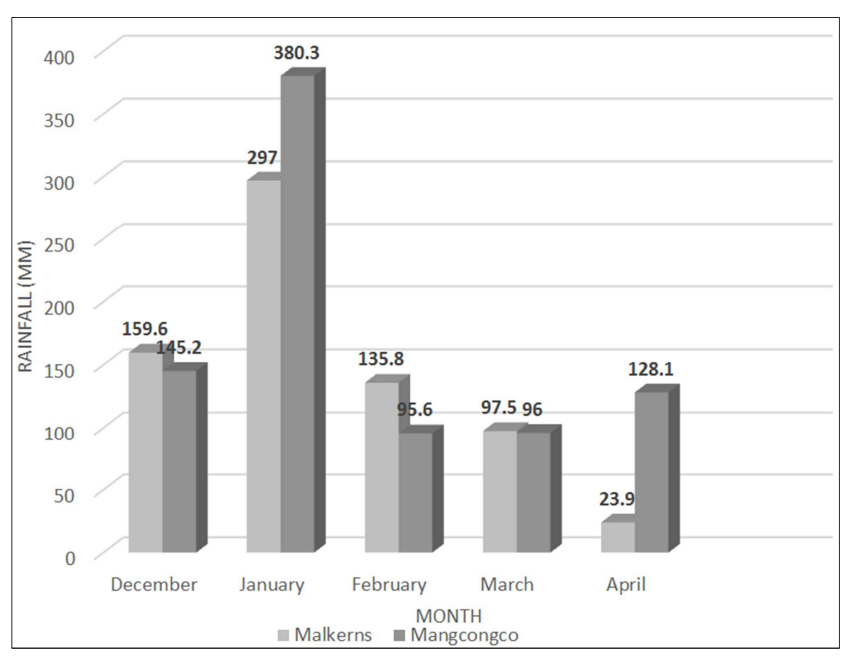

Figure 1. Rainfall data during 2014/2015 cropping season in Malkerns and Mangcongco.

\subsection{Soil Characteristics}

The soil pH before liming was 4.2 and 3.4 for Malkerns 
and Mangcongco respectively. Soil $\mathrm{pH}$ most favourable to herbicides is 6.5 to 7.3 as microbes are most active at a neutral soil $\mathrm{pH}$ and are the primary means by which most of the non-ionic herbicides are degraded, hence the thought that not much of the differences in efficacy could be attributable to $\mathrm{pH}$ as the soil were neutralised to $\mathrm{pH} 7$ through liming before planting.. The organic matter in Malkerns was $8.5 \%$, and for Mangcongco it was $6.7 \%$. According to [26], a fertile soil rich in organic matter may promote faster degradation of an herbicide, hence the better weed control efficiency of the weeds in Malkerns as compared to Mangcongco. Malkerns soils had high organic matter, hence, had high cation exchange capacity which influenced the absorption and translocation of herbicides positively. In terms of clay content Mangcongco had the highest $(22.9 \%)$ and Malkerns (17.6\%) and also Mangcongco had the highest sand particles $(78.0 \%)$ as compared to Malkerns (71.6\%) (Table 2). [27], also found that adsorption was least on sandy loam, which had the lowest clay and organic matter content, which is also true for this study as Mangcongco had the lowest clay and organic matter content hence the least adsorption.

Table 2. The soil characteristics for Malkerns Research Station and Mangcongco Experimental site.

\begin{tabular}{lll}
\hline Soil Parameter & Malkerns & Mangcongco \\
\hline Soil $\mathrm{pH} \mathrm{CaCl}_{2}$ before liming & 4.2 & 3.4 \\
Exchangeable acidity & $2.0 \mathrm{meq} / 100 \mathrm{~g}$ & $2.0 \mathrm{meq} / 100 \mathrm{~g}$ \\
Organic matter & $8.5 \%$ & $6.7 \%$ \\
& Sand $71.6 \%$ & Sand $78.0 \%$ \\
Clay content & Silt $5.4 \%$ & Silt $4 \%$ \\
& Clay $17.6 \%$ & Clay $22.8 \%$ \\
Tetural class & Sandy loam & Sandy Clay Loam \\
\hline
\end{tabular}

\subsection{Predominant Weed Flora}

In Malkerns most of the predominant weed species were broadleaves. Immediately after emergence of maize the most noticeable weeds were Oxalis latifolia and Xanthum strumarium. Other broadleaves found were; Nicandra physalodes, Euphorbia heterophylla, Acanthospermum hispidum, Corchorus olitorius, Bidens pilosa, Amaranthus hybridus and Ipomea purpurea. The dominant grass species in Malkerns were Cynadon dactylon and Pacinum maximum. In Mangcogco sedges were highly dominant as compared to the broadleaves. Weed competition appeared to be very severe from 8 weeks after planting, probably because the temperatures had begun to rise hence breaking of dormancy for the weed species. Two grass species were also found; Cynadon dactylon and Eleusine indica, with Eleusine indica the most dominant in all treatments. Broadleaves had very low populations in Mangcongco and were; Tagetes minuta, Portulaca oleracea, Cleome monopylla, Oxalis latifolia, Bidens pilosa, Richardia scabra and Ipomoea purpurea (Table 3).
Table 3. Scientific names, families and life form and categories of weeds in the two experimental sites.

\begin{tabular}{lll}
\hline Scientific name & Family & Life form (Category) \\
\hline Malkerns & & \\
Xanthum strumarium & Asteraceae & Annual (Broadleaves) \\
Nicandra physalodes & Solanaceae & Annual (Broadleaves) \\
Euphorbia heterophylla & Euphorbiaceae & Annual (Broadleaves) \\
Acanthospermum hispidum & Asteraceae & Annual (Broadleaves) \\
Corchorus olitorius & Malvaceae & Annual (Broadleaves) \\
Bidens pilosa & Asteraceae & Annual (Broadleaves) \\
Oxalis latifolia & Oxilidaceae & Annual (Broadleaves) \\
Amaranthus hybridus & Amaranthaceae & Annual (Broadleaves) \\
Ipomoea purpurea & Convolvulaceae & Perennial (Broadleaves) \\
Cynadon dactylon & Poaceae & Perennial (Grass) \\
Panicum maximum & Poaceae & Perennial (Grass) \\
Mangcongco & & \\
Tagetes minuta & Asteraceae & Annual (Broadleaves) \\
Portulaca oleracea & Portulacaceae & Annual (Broadleaves) \\
Cleome monopylla & Capparaceae & Annual (Broadleaves) \\
Oxalis latifolia & Oxilidaceae & Annual (Broadleaves) \\
Bidens pilosa & Asteraceae & Annual (Broadleaves) \\
Richardia scabra & Rubiaceae & Annual (Broadleaves) \\
Ipomoea purpurea & Convolvulaceae & Annual (Broadleaves) \\
Cynadon dactylon & Poaceae & Perennial (Grass) \\
Eleusine indica & Poaceae & Annual (Grass) \\
Cyperus rotundus & Cyperaceae & Perennial (Sedge) \\
\hline & &
\end{tabular}

\subsection{Effect on Weed Control Efficiency}

\subsubsection{Weed Control Efficiency for Broadleaves}

There were significant $(\mathrm{P}<0.05)$ differences in weed control efficiency of broadleaves for all treatments in Malkerns at 8,12 and 16 WAP. The maximum weed control efficiency for broadleaves was $97 \%$ with the treatment Lumax at the rate of $\%$ clay content recommendation $(4 \mathrm{~L} / \mathrm{ha})$ at 8 WAP. However, this treatment did not maintain high-performance residual activity of weeds through crop canopy. This means it was among the treatments that reduced broadleaves population most effectively through to crop canopy. The higher weed control efficiency with this treatment could be attributed to the efficiency in the herbicide and the rate in controlling broadleaves and also attributed to the lower weed population as well as dry matter accumulation of weeds. [30], reported findings in 21 American university trials conducted across the Corn Belt in 2004 which showed indications that Lumax provided the best overall weed control (92\% control on average across all grass and broadleaf weeds tested). The competitive products exhibited overall weed control no higher than $87 \%$. The least efficient herbicide to control broadleaves was 2,4-D Amine 480 at full rate of the retailer's recommended dose $2 \mathrm{~L} / \mathrm{ha}$ in all weeks. [3], evaluated the efficacy of some reduced rates of some post-emergence herbicides in Iran and reported that some weed species could be controlled with reduced herbicide rates.

In Mangcongco weed control efficiency for broadleaves was significant in treatments at 12 WAP only. Maximum weed control in Mangcongco was $76 \%$, with the treatment of Gardomil Gold at the full dose recommended by the retailers (3.2 L/ha), at $16 \mathrm{WAP}$. Bladex Plus $500 \mathrm{SC}$, at 3.6 
L/ha the $\%$ clay content recommended dose was the least efficient herbicide in controlling broadleaves.

There was no significant $(\mathrm{P}<0.05)$ difference in weed control efficiency between the two sites (Table 4). All treatment means in 8,12 and 16 WAP showed negative weed control efficiency and there was increase in the weed control efficiency over time and this must have been due to the fact that the crop had formed canopy hence less light for weed growth.

Table 4. Weed Control Efficiency for broadleaves in all treatments at 8, 12 and 16 weeks after planting.

\begin{tabular}{|c|c|c|c|c|c|c|}
\hline \multirow{3}{*}{ Treatments } & \multicolumn{6}{|l|}{ Site } \\
\hline & \multicolumn{3}{|c|}{ Malkerns } & \multicolumn{3}{|c|}{ Mangcongco } \\
\hline & 8 & 12 & 16 & 8 & 12 & 16 \\
\hline \multicolumn{7}{|l|}{$\begin{array}{l}\text { Herbicides } \\
\text { Interaction (Herbicide } \mathrm{x} \text { rate } \mathrm{x} \text { site) }\end{array}$} \\
\hline No herbicide, control (hand hoeing) & $0 \mathrm{~b}$ & $0 \mathrm{~b}$ & $0 \mathrm{a}$ & $0 \mathrm{a}$ & $0 \mathrm{~b}$ & $0 \mathrm{a}$ \\
\hline Bladex Plus $500 \mathrm{SC}$, at $3.6 \mathrm{~L} / \mathrm{ha}$ & $22 b$ & $-218 b$ & $22 b$ & $-820 a$ & $-490 a$ & $-323 a$ \\
\hline Bladex Plus $500 \mathrm{SC}$, at $2 \mathrm{~L} / \mathrm{ha}$ & $37 \mathrm{~b}$ & $-25 b$ & $-92 \mathrm{a}$ & $-3 a$ & $64 b$ & $71 \mathrm{a}$ \\
\hline Bladex Plus $500 \mathrm{SC}$, at $4 \mathrm{~L} / \mathrm{ha}$ & $-18 b$ & $41 b$ & $48 b$ & $-25 a$ & $11 \mathrm{~b}$ & $16 \mathrm{a}$ \\
\hline No herbicide, control (hand hoeing) & $0 \mathrm{~b}$ & $0 \mathrm{~b}$ & $0 \mathrm{a}$ & $0 \mathrm{a}$ & $0 \mathrm{~b}$ & $0 \mathrm{a}$ \\
\hline Gardomil Gold, at $3.2 \mathrm{~L} / \mathrm{ha}$ & $71 b$ & $57 \mathrm{~b}$ & $72 b$ & $24 a$ & $49 b$ & $58 \mathrm{a}$ \\
\hline Gardomil Gold, at $1.6 \mathrm{~L} / \mathrm{ha}$ & $-1733 a$ & $-822 \mathrm{a}$ & $-274 a$ & $68 \mathrm{a}$ & $73 b$ & $75 \mathrm{a}$ \\
\hline Gardomil Gold, at $3.2 \mathrm{~L} / \mathrm{ha}$ & $-13 b$ & $-41 b$ & $-391 \mathrm{a}$ & $65 \mathrm{a}$ & $70 \mathrm{~b}$ & $76 a$ \\
\hline No herbicide, control (hand hoeing) & $0 \mathrm{~b}$ & $0 \mathrm{~b}$ & $0 \mathrm{a}$ & $0 \mathrm{a}$ & $0 \mathrm{~b}$ & $0 \mathrm{a}$ \\
\hline Lumax, at $4 \mathrm{~L} / \mathrm{ha}$ & $97 b$ & $93 b$ & $84 b$ & $59 a$ & $59 \mathrm{~b}$ & $73 a$ \\
\hline Lumax, at $1 \mathrm{~L} / \mathrm{ha}$ & $59 b$ & $58 \mathrm{~b}$ & $-50 a$ & $-260 a$ & $-70 a$ & $23 \mathrm{a}$ \\
\hline Lumax, at $2 \mathrm{~L} / \mathrm{ha}$ & $71 b$ & $60 \mathrm{~b}$ & $43 b$ & $-89 a$ & $-1 b$ & $25 \mathrm{a}$ \\
\hline No herbicide, control (hand hoeing) & $0 \mathrm{~b}$ & $0 \mathrm{~b}$ & $0 \mathrm{a}$ & $0 \mathrm{a}$ & $0 \mathrm{~b}$ & $0 \mathrm{a}$ \\
\hline 2,4-D Amine 480 , at $4.3 \mathrm{~L} / \mathrm{ha}$ & $44 b$ & $58 \mathrm{~b}$ & $21 b$ & $-22 a$ & $-56 b$ & $-31 \mathrm{a}$ \\
\hline 2,4-D Amine 480 , at $1 \mathrm{~L} / \mathrm{ha}$ & $-38 b$ & $31 b$ & $32 b$ & $39 a$ & $51 b$ & $35 \mathrm{a}$ \\
\hline 2,4-D Amine 480 , at $2 \mathrm{~L} / \mathrm{ha}$ & $-1812 \mathrm{a}$ & $-457 a$ & $-407 a$ & $-121 a$ & $-327 a$ & $-218 \mathrm{a}$ \\
\hline Significance & $*$ & $*$ & $*$ & NS & $*$ & NS \\
\hline Site & Malkerns & & & Mangc & & \\
\hline Mean & $-201 \mathrm{a}$ & $-73 a$ & $-56 a$ & $-68 \mathrm{a}$ & $-35 a$ & $-7 \mathrm{a}$ \\
\hline Significance & NS & NS & NS & NS & NS & NS \\
\hline $\mathrm{CV} \%$ & 697.2 & 722.1 & 924.4 & 697.2 & 722.1 & 924.4 \\
\hline
\end{tabular}

Mean values within the same column followed by the same letter are not significantly different at LSD P $<0.05$.

*Significant at $\mathrm{P}<0.05 * *$ Significant at $\mathrm{P}<0.01 \mathrm{NS}=$ Not significant

\subsubsection{Weed Control Efficiency for Grasses}

There were no significant $(\mathrm{P}<0.05)$ differences in weed control efficiency for grasses in all the treatments at 8,12 and 16 WAP for both sites. It is evident from the results that all the herbicides were not efficient in controlling grass species. In Malkerns the most predominant weed flora were broadleaves, with a very low weed density on grasses. Malkerns results show that all herbicides at all rates were not effective in controlling the grass species as all numbers were negative.

There was also no significant $(\mathrm{P}<0.05)$ difference in weed control efficiency for grasses in the two sites, Malkerns and Mangcongco. The highest weed control efficiency of 30\% was in Mangcongco with the treatment of Gardomil Gold at the full rate recommended by retailers, $3.2 \mathrm{~L} /$ ha (Table 5). This treatments showed the best result both at 12 and 16 WAP. The lowest efficacy for grasses was negative which means there was no efficacy in controlling grasses using Lumax at $3.6 \mathrm{~L} / \mathrm{ha}$. The lower weed control efficiencies of grasses might be due to higher weed intensity and dry matter accumulation of weeds in these treatments. The higher weed densities in grass species were responsible for competition for nutrients, soil moisture, light and carbon dioxide and considerably reduced the plant biomass. These results corroborate with the findings of [13], which showed no significant difference in weed control efficiency with use of different herbicides.

Table 5. Weed Control Efficiency for grasses in all treatments at 8, 12 and 16 weeks after planting.

\begin{tabular}{|c|c|c|c|c|c|c|}
\hline \multirow{3}{*}{ Treatments } & \multicolumn{6}{|l|}{ Site } \\
\hline & \multicolumn{3}{|c|}{ Malkerns } & \multicolumn{3}{|c|}{ Mangcongco } \\
\hline & 8 & 12 & 16 & 8 & 12 & 16 \\
\hline No herbicide, control (hand hoeing) & $0 \mathrm{a}$ & $0 \mathrm{a}$ & $0 \mathrm{a}$ & $0 \mathrm{a}$ & $0 \mathrm{a}$ & $0 \mathrm{a}$ \\
\hline Bladex Plus $500 \mathrm{SC}$, at $3.6 \mathrm{~L} / \mathrm{ha}$ & $-1278 \mathrm{a}$ & $-2049 a$ & $-257 a$ & $-6 a$ & $-45 a$ & $-77 a$ \\
\hline Bladex Plus $500 \mathrm{SC}$, at $2 \mathrm{~L} / \mathrm{ha}$ & $-1906 a$ & $-3059 a$ & $-95 \mathrm{a}$ & $-57 \mathrm{a}$ & $-74 a$ & $-75 a$ \\
\hline Bladex Plus $500 \mathrm{SC}$, at $4 \mathrm{~L} / \mathrm{ha}$ & $-1595 a$ & $-2527 a$ & $-270 a$ & $-143 a$ & $-84 a$ & $-34 a$ \\
\hline No herbicide, control (hand hoeing)) & $0 \mathrm{a}$ & $0 \mathrm{a}$ & 0a & $0 \mathrm{a}$ & 0a & $0 \mathrm{a}$ \\
\hline Gardomil Gold, at $1.6 \mathrm{~L} / \mathrm{ha}$ & $-598 a$ & $-520 a$ & $-986 a$ & $-82 \mathrm{a}$ & $8 \mathrm{a}$ & $25 \mathrm{a}$ \\
\hline Gardomil Gold, at $3.2 \mathrm{~L} / \mathrm{ha}$ & $-2955 a$ & $-7107 a$ & $-1202 a$ & $-40 a$ & $10 \mathrm{a}$ & $30 \mathrm{a}$ \\
\hline No herbicide, control (hand hoeing) & $0 \mathrm{a}$ & $0 \mathrm{a}$ & $0 \mathrm{a}$ & $0 \mathrm{a}$ & $0 \mathrm{a}$ & $0 \mathrm{a}$ \\
\hline
\end{tabular}




\begin{tabular}{|c|c|c|c|c|c|c|}
\hline \multirow{3}{*}{ Treatments } & \multicolumn{6}{|l|}{ Site } \\
\hline & \multicolumn{3}{|l|}{ Malkerns } & \multicolumn{3}{|c|}{ Mangcongco } \\
\hline & 8 & 12 & 16 & 8 & 12 & 16 \\
\hline Lumax, at $4 \mathrm{~L} / \mathrm{ha}$ & $-196 a$ & $-366 a$ & $-469 a$ & $-245 a$ & $-71 a$ & $-77 a$ \\
\hline Lumax, at $1 \mathrm{~L} / \mathrm{ha}$ & $-115 a$ & $-104 a$ & $-226 a$ & $-157 a$ & $-140 \mathrm{a}$ & $-161 \mathrm{a}$ \\
\hline Lumax, at $2 \mathrm{~L} / \mathrm{ha}$ & $-281 a$ & $-215 a$ & $-287 a$ & $-187 a$ & $-112 a$ & $-69 a$ \\
\hline No herbicide, control (hand hoeing) & 0a & $0 \mathrm{a}$ & $0 \mathrm{a}$ & 0a & $0 \mathrm{a}$ & $0 \mathrm{a}$ \\
\hline 2,4-D Amine 480 , at $4.3 \mathrm{~L} / \mathrm{ha}$ & $-3974 a$ & $-2605 a$ & $-220 a$ & $-74 a$ & $-64 a$ & $-46 a$ \\
\hline 2,4-D Amine 480 , at $1 \mathrm{~L} / \mathrm{ha}$ & $-8566 a$ & $-5900 \mathrm{a}$ & $-229 a$ & $-29 a$ & $-24 a$ & $-28 \mathrm{a}$ \\
\hline 2,4-D Amine 480 , at $2 \mathrm{~L} / \mathrm{ha}$ & $-26667 a$ & $-5403 a$ & $-288 a$ & $-40 \mathrm{a}$ & $-45 a$ & $-11 \mathrm{a}$ \\
\hline Significance & NS & NS & NS & NS & NS & NS \\
\hline Site & \multicolumn{3}{|l|}{ Malkerns } & \multicolumn{3}{|c|}{ Mangcongco } \\
\hline Mean & $-3217 \mathrm{a}$ & $-2014 a$ & $-366 a$ & $-67 a$ & $-40 a$ & $-32 a$ \\
\hline Significance & NS & NS & NS & NS & NS & NS \\
\hline CV\% & 602.2 & 378.8 & 289.9 & 602.2 & 378.8 & 289.9 \\
\hline
\end{tabular}

Mean values within the same column followed by the same letter are not significantly different at LSD P $<0.05$.

*Significant at $\mathrm{P}<0.05 * *$ Significant at $\mathrm{P}<0.01, \mathrm{NS}=$ Not significant

\subsubsection{Weed Control Efficiency for Sedges}

There was a significant $(\mathrm{P}<0.05)$ difference in weed control efficiency of grasses between the treatments in Malkerns at 8,12 and 16 WAP. At 8 WAP the highest weed control efficiency was $60 \%$ with the treatment Gardomil Gold at full the rate recommended by retailers, $3.2 \mathrm{~L} / \mathrm{ha}$. But at later stage the treatment showed lower efficiency which might be due to emergence of some new sedge species. The lowest efficacy was with the use of 2,4-D Amine 480 at 2 L/ha. At 16 WAP Bladex Plus at the rate based on the $\%$ clay content in the soil, showed a higher efficacy of $33 \%$ as compared to other treatments (Table 6). Herbicides did differ significantly in controlling the sedges in all the treatments in Malkerns. Most of the herbicides were not very effective in controlling sedges.
In Mangcongco there were no significant $(\mathrm{P}<0.05)$ differences in weed control efficiency in all treatments at 8 , 12 and 16 WAP. The highest efficacy was $28 \%$, in the treatment Gardomil Gold at half the rate recommended by retailers at 16 WAP. Contrary to the results by [10] who reported increases in rates of application of herbicides, with corresponding increases in percent reductions in weed population but these increases were not significantly different for rates of application but were significant for herbicides. However, [22], reported that some weeds that occur in maize in Italy could be controlled by $1 / 6$ of the recommended herbicide rate of mesotrione, while some other weeds could not be controlled, even at the recommended rate. There was no significant $(\mathrm{P}<0.05)$ difference in weed control efficiency between treatments in the two sites.

Table 6. Weed Control Efficiency for sedges in all treatments at 8,12 and 16 weeks after planting.

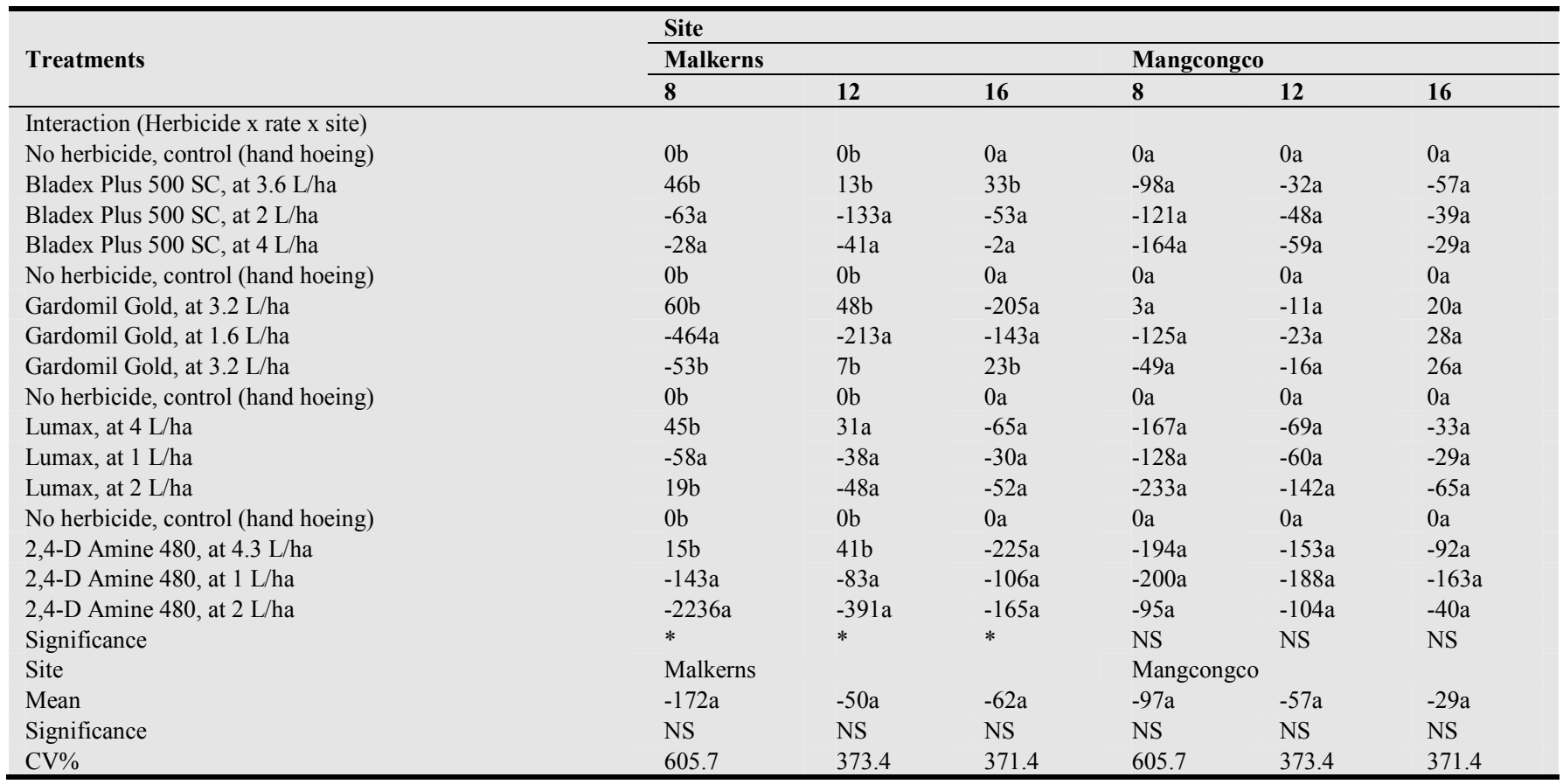

Mean values within the same column followed by the same letter are not significantly different at $\operatorname{LSD} \mathrm{P}<0.05$.

*Significant at $\mathrm{P}<0.05 * *$ Significant at $\mathrm{P}<0.01 \mathrm{NS}=$ Not significant 


\subsection{Effect on Plant Height}

The use of the various herbicides treatments did not affect significantly $(\mathrm{P}<0.05)$ the plant height in all the weeks for both sites. The highest mean plant height in Malkerns at 12 WAP was $238.1 \mathrm{~cm}$ with the treatment of Bladex Plus $500 \mathrm{SC}$ at $2 \mathrm{~L} / \mathrm{ha}$, the retailer's half recommended rate, and $176.1 \mathrm{~cm}$ in Mangcongco in the control treatment. (Table 7).

The similarity in plant height among the treatments and their interaction with herbicides show that plant height is strictly governed by genetic control and environment has a major effect on it. The non-significant effects of various treatments on plant height may be due to the reduced growth of weeds. [24], also found that maize plant height was not affected significantly by different herbicide treatments. However, numerically the tallest plants were recorded from Malkerns at 12 weeks after planting with the treatment of Bladex Plus at a rate of $2 \mathrm{~L} / \mathrm{ha}$ and was $238.1 \mathrm{~cm}$ and the lowest for that site at $143.9 \mathrm{~cm}$ at $8 \mathrm{WAP}$, with the treatment, 2,4-D Amine at the rate based on the clay content in the soil. These results are contradictory to the findings of [14] who reported that different treatments had a significant $(\mathrm{P}<0.05)$ effect on plant height, mainly due to the various intensities of weed competition with maize plant. Plant height is a key factor that contributes significantly to maize biological and grain yield because taller plants capture more light and therefore have more photosynthate available for grain filling
[18]. [29], reported that plant height was not significantly affected by various herbicide treatments.

There was a significant $(\mathrm{P}<0.05)$ difference in plant height between the two sites with Mangcongco having an average variation in plant height of 69.2 to $168.5 \mathrm{~cm}$. The low plant height in Mangcongco was associated with poor weed management. This significance might have been due to enormous amount of rainfall received in Mangcongco just after planting which resulted in difficulties in seedling emergence hence, seedlings leafing out underground. The higher plant height in Malkerns played an important growth character which directly linked to the grain production. [11], also found that duration of weed infestation significantly affected plant height. Both the lowest and highest plant height was with the herbicide Gardomil Gold at $2.5 \mathrm{~L} / \mathrm{ha}$ and 1.6 L/ha respectively. [16] and [29] observed that using different methods of weed control plant height was nonsignificantly affected by various herbicide treatments.

The rate of increase in maize height under all treatments in both sites seemed to be constant in week 10 and 12 WAP after the rapid increase from week 8. [21], stated that after flowering, the reproductive sink becomes extremely strong, and limits assimilates partitioned for additional leaf, stem and roots growth and he also reiterated that in determinate species, leaf and stem growth cease at flowering.

Table 7. Maize plant height (cm) at 8, 10 and 12 weeks after planting for both sites.

\begin{tabular}{|c|c|c|c|c|c|c|}
\hline \multirow{3}{*}{ Treatments } & \multicolumn{6}{|l|}{ Site } \\
\hline & \multicolumn{3}{|c|}{ Malkerns (WAP) } & \multicolumn{3}{|c|}{ Mangcongco (WAP) } \\
\hline & 8 & 10 & 12 & 8 & 10 & 12 \\
\hline \multicolumn{7}{|l|}{ Interaction (Herbicide $\mathrm{x}$ rate $\mathrm{x}$ site) } \\
\hline No herbicide, control (hand hoeing) & $164.1 \mathrm{a}$ & $220.6 \mathrm{a}$ & $220.5 \mathrm{a}$ & $67.2 \mathrm{a}$ & $175.3 \mathrm{a}$ & $173.2 \mathrm{a}$ \\
\hline Bladex Plus $500 \mathrm{SC}$, at $3.6 \mathrm{~L} / \mathrm{ha}$ & $157.2 \mathrm{a}$ & $224.1 \mathrm{a}$ & $217.6 \mathrm{a}$ & $75.7 \mathrm{a}$ & $162.3 \mathrm{a}$ & $170.2 \mathrm{a}$ \\
\hline Bladex Plus $500 \mathrm{SC}$, at $2 \mathrm{~L} / \mathrm{ha}$ & $167.1 \mathrm{a}$ & $218.4 \mathrm{a}$ & 238.1a & $69.7 \mathrm{a}$ & $166.1 \mathrm{a}$ & $172.4 \mathrm{a}$ \\
\hline Bladex Plus $500 \mathrm{SC}$, at $4 \mathrm{~L} / \mathrm{ha}$ & $175.3 \mathrm{a}$ & $218.6 \mathrm{a}$ & $229.4 a$ & $65.8 \mathrm{a}$ & $165.9 \mathrm{a}$ & $155.8 \mathrm{a}$ \\
\hline No herbicide, control (hand hoeing) & $165.3 \mathrm{a}$ & $219.2 \mathrm{a}$ & $224.2 \mathrm{a}$ & $74.9 \mathrm{a}$ & $165.2 \mathrm{a}$ & $168.2 \mathrm{a}$ \\
\hline Gardomil Gold, at $3.2 \mathrm{~L} / \mathrm{ha}$ & $162.4 \mathrm{a}$ & $220.9 a$ & $225.8 \mathrm{a}$ & $69.2 \mathrm{a}$ & $163.8 \mathrm{a}$ & $170.9 \mathrm{a}$ \\
\hline Gardomil Gold, at $1.6 \mathrm{~L} / \mathrm{ha}$ & $146.0 \mathrm{a}$ & $225.7 \mathrm{a}$ & $221.6 \mathrm{a}$ & $73.5 \mathrm{a}$ & $177.3 \mathrm{a}$ & $166.5 \mathrm{a}$ \\
\hline Gardomil Gold, at $3.2 \mathrm{~L} / \mathrm{ha}$ & $150.0 \mathrm{a}$ & $222.5 \mathrm{a}$ & $220.5 \mathrm{a}$ & $65.0 \mathrm{a}$ & $176.8 \mathrm{a}$ & $174.2 \mathrm{a}$ \\
\hline No herbicide, control (hand hoeing) & $165.2 \mathrm{a}$ & $228.6 \mathrm{a}$ & $219.4 a$ & $64.2 \mathrm{a}$ & $173.4 \mathrm{a}$ & $176.1 \mathrm{a}$ \\
\hline Lumax, at $4 \mathrm{~L} / \mathrm{ha}$ & $157.0 \mathrm{a}$ & $225.1 \mathrm{a}$ & $225.5 \mathrm{a}$ & $75.5 \mathrm{a}$ & $170.9 \mathrm{a}$ & $172.6 \mathrm{a}$ \\
\hline Lumax, at $1 \mathrm{~L} / \mathrm{ha}$ & $151.1 \mathrm{a}$ & $208.4 \mathrm{a}$ & $227.7 \mathrm{a}$ & $66.1 \mathrm{a}$ & $173.3 \mathrm{a}$ & $167.9 \mathrm{a}$ \\
\hline Lumax, at $2 \mathrm{~L} / \mathrm{ha}$ & $162.7 \mathrm{a}$ & $226.8 \mathrm{a}$ & $225.2 \mathrm{a}$ & $65.8 \mathrm{a}$ & $160.6 \mathrm{a}$ & $175.5 \mathrm{a}$ \\
\hline No herbicide, control (hand hoeing) & $164.4 \mathrm{a}$ & $223.2 \mathrm{a}$ & $224.8 \mathrm{a}$ & $67.0 \mathrm{a}$ & $173.8 \mathrm{a}$ & $171.5 \mathrm{a}$ \\
\hline 2,4-D Amine 480, at $4.3 \mathrm{~L} / \mathrm{ha}$ & $143.9 \mathrm{a}$ & $225.7 \mathrm{a}$ & $223.7 \mathrm{a}$ & $66.2 \mathrm{a}$ & $154.1 \mathrm{a}$ & $157.2 \mathrm{a}$ \\
\hline 2,4-D Amine 480, at $1 \mathrm{~L} / \mathrm{ha}$ & $154.0 \mathrm{a}$ & $222.0 \mathrm{a}$ & $228.7 \mathrm{a}$ & $71.4 \mathrm{a}$ & $169.8 \mathrm{a}$ & $166.2 \mathrm{a}$ \\
\hline 2,4-D Amine 480, at $2 \mathrm{~L} / \mathrm{ha}$ & 162.0 & $230.9 \mathrm{a}$ & $226.1 \mathrm{a}$ & $70.2 \mathrm{a}$ & $165.9 \mathrm{a}$ & $158.4 \mathrm{a}$ \\
\hline Significance & NS & NS & NS & NS & NS & NS \\
\hline Sites & \multicolumn{3}{|c|}{ Malkerns } & \multicolumn{3}{|c|}{ Mangcongco } \\
\hline Mean & $159.3 \mathrm{~b}$ & $222.6 \mathrm{~b}$ & $224.9 \mathrm{~b}$ & $69.2 \mathrm{a}$ & $168.4 \mathrm{a}$ & $168.5 \mathrm{a}$ \\
\hline Significance & ** & ** & ** & $* *$ & $* *$ & ** \\
\hline CV\% & 10.4 & 6.3 & 6.4 & 10.4 & 6.3 & 6.4 \\
\hline
\end{tabular}

Mean values within the same column followed by the same letter are not significantly different at $\mathrm{LSD} P<0.05$.

*Significant at $\mathrm{P}<0.05 * *$ Significant at $\mathrm{P}<0.01 \mathrm{NS}=$ Not significant 


\subsection{Effect on Leaf Area Index}

Leaf area index varied due to the variation of the weed control methods. In Malkerns there was a significant $(\mathrm{P}<$ $0.05)$ difference in LAI in treatments at 8 WAP but with no significant difference at 10 and $12 \mathrm{WAP}$. The maximum LAI was 2.03 in one of the control treatments and the minimum was 1.51 with the treatment of Lumax $2 \mathrm{~L} /$ ha the full rate recommended by the retailers at 12 WAP (Table 8 ) hand hoeing at 8 WAP. Khan et al. (2003), reported that leaf area was significantly $(\mathrm{P}<0.05)$ affected by different treatments of herbicides and maximum leaf area was recorded in hand weeded plots at tasseling which was comparable with plots receiving herbicide treatments.

There was a significant $(\mathrm{P}<0.05)$ difference in LAI in all treatments in Mangcongco at 8, 10 and 12 WAP. The maximum LAI was at $10 \mathrm{WAP}$ and was 1.98 in the treatment Gardomil Gold at the full rate recommended by retailers. This may have been due to the fact that Gardomil Gold at 3.2 $\mathrm{L} / \mathrm{ha}$ was the most effective in control of weeds and even at 12 WAP it still maintained the maximum LAI.
There were significant $(\mathrm{P}<0.05)$ differences in LAI in the two sites. Malkerns had the highest mean LAI in all the weeks as compared to Malkerns. This might have due to the fact that maize grown in Malkerns intercepted incident photon flux better, accumulated more dry matter and yielded more grains than plants in Mangcongco as the temperatures were lower. The trend in the influence of weed control treatments on LAI showed that LAI increased from 8 WAP and 10 WAP, but there was a decline at $12 \mathrm{WAP}$ for both sites. The probable indication of these findings was that the LAI was reduced with time, resulting in high weed competition for growth factors, especially, for light. [16], observed that using weedy control as checks, the lower leaves of maize are suppressed leading to their early senescence, hence fewer leaves and subsequently lower leaf area index. The findings of the present study agree with the findings by [32] which revealed that high competitions by weeds reduced LAI in maize at blooming by $15 \%$. As leaf is the basic photosynthetic machinery for plant food, hence its size would directly affect the yield and yield components of crop [1].

Table 8. Leaf Area Index of maize at 8, 10 and 12 weeks after planting.

\begin{tabular}{|c|c|c|c|c|c|c|}
\hline \multirow{3}{*}{ Treatments } & \multicolumn{6}{|l|}{ Site } \\
\hline & \multicolumn{3}{|c|}{ Malkerns } & \multicolumn{3}{|c|}{ Mangcongco } \\
\hline & 8 & 10 & 12 & 8 & 10 & 12 \\
\hline \multicolumn{7}{|l|}{ Interaction (Herbicide $\mathrm{x}$ rate $\mathrm{x}$ site) } \\
\hline No herbicide, control (hand hoeing) & $1.87 \mathrm{a}$ & $1.89 \mathrm{a}$ & $1.59 \mathrm{a}$ & $0.77 \mathrm{a}$ & $1.71 \mathrm{a}$ & $1.77 \mathrm{~b}$ \\
\hline Bladex Plus $500 \mathrm{SC}$, at $3.6 \mathrm{~L} / \mathrm{ha}$ & $1.75 \mathrm{a}$ & $1.89 \mathrm{a}$ & $1.59 \mathrm{a}$ & $0.92 \mathrm{a}$ & $1.71 \mathrm{a}$ & $1.65 \mathrm{~b}$ \\
\hline Bladex Plus $500 \mathrm{SC}$, at $2 \mathrm{~L} / \mathrm{ha}$ & $1.93 a$ & $1.67 \mathrm{a}$ & $1.77 \mathrm{a}$ & $0.91 \mathrm{a}$ & $1.74 \mathrm{a}$ & $1.85 \mathrm{~b}$ \\
\hline Bladex Plus $500 \mathrm{SC}$, at $4 \mathrm{~L} / \mathrm{ha}$ & $1.91 \mathrm{a}$ & $1.76 \mathrm{a}$ & $1.61 \mathrm{a}$ & $0.76 \mathrm{a}$ & $1.52 \mathrm{a}$ & $1.59 \mathrm{a}$ \\
\hline No herbicide, control (hand hoeing) & $1.98 \mathrm{a}$ & $1.87 \mathrm{a}$ & $1.63 \mathrm{a}$ & $0.83 \mathrm{a}$ & $1.74 \mathrm{a}$ & $1.60 \mathrm{~b}$ \\
\hline Gardomil Gold, at $3.2 \mathrm{~L} / \mathrm{ha}$ & $1.74 \mathrm{a}$ & $1.67 \mathrm{a}$ & $1.70 \mathrm{a}$ & $0.79 \mathrm{a}$ & $1.60 \mathrm{a}$ & $1.55 \mathrm{a}$ \\
\hline Gardomil Gold, at $1.6 \mathrm{~L} / \mathrm{ha}$ & $1.68 \mathrm{a}$ & $1.70 \mathrm{a}$ & $1.78 \mathrm{a}$ & $0.87 \mathrm{a}$ & $1.77 \mathrm{a}$ & $1.67 \mathrm{~b}$ \\
\hline Gardomil Gold, at $3.2 \mathrm{~L} / \mathrm{ha}$ & $1.72 \mathrm{a}$ & $1.80 \mathrm{a}$ & $1.58 \mathrm{a}$ & $0.69 \mathrm{a}$ & $1.98 \mathrm{~b}$ & $1.88 \mathrm{~b}$ \\
\hline No herbicide, control (hand hoeing) & $1.78 \mathrm{a}$ & $1.78 \mathrm{a}$ & $1.61 \mathrm{a}$ & $0.80 \mathrm{a}$ & $1.60 \mathrm{a}$ & $1.70 \mathrm{~b}$ \\
\hline Lumax, at $4 \mathrm{~L} / \mathrm{ha}$ & $1.69 \mathrm{a}$ & $1.73 \mathrm{a}$ & $1.67 \mathrm{a}$ & $0.99 \mathrm{~b}$ & $1.74 \mathrm{a}$ & $1.69 \mathrm{~b}$ \\
\hline Lumax, at $1 \mathrm{~L} / \mathrm{ha}$ & $1.91 \mathrm{a}$ & $1.64 \mathrm{a}$ & $1.70 \mathrm{a}$ & $0.73 \mathrm{a}$ & $1.64 \mathrm{a}$ & $1.60 \mathrm{a}$ \\
\hline Lumax, at $2 \mathrm{~L} / \mathrm{ha}$ & $1.92 \mathrm{a}$ & $1.91 \mathrm{a}$ & $1.51 \mathrm{a}$ & $0.75 \mathrm{a}$ & $1.63 \mathrm{a}$ & $1.72 b$ \\
\hline No herbicide, control (hand hoeing) & $2.03 b$ & $1.91 \mathrm{a}$ & $1.71 \mathrm{a}$ & $0.80 \mathrm{a}$ & $1.85 b$ & $1.80 \mathrm{~b}$ \\
\hline 2,4-D Amine 480 , at $4.3 \mathrm{~L} / \mathrm{ha}$ & $1.84 \mathrm{a}$ & $1.74 \mathrm{a}$ & $1.74 \mathrm{a}$ & $0.77 \mathrm{a}$ & $1.42 \mathrm{a}$ & $1.24 \mathrm{a}$ \\
\hline 2,4-D Amine 480, at $1 \mathrm{~L} / \mathrm{ha}$ & $1.82 \mathrm{a}$ & $1.73 \mathrm{a}$ & $1.71 \mathrm{a}$ & $0.84 \mathrm{a}$ & $1.67 \mathrm{a}$ & $1.66 \mathrm{~b}$ \\
\hline 2,4-D Amine 480 , at $2 \mathrm{~L} / \mathrm{ha}$ & $1.78 \mathrm{a}$ & $1.81 \mathrm{a}$ & $1.76 \mathrm{a}$ & $0.86 \mathrm{a}$ & $1.69 \mathrm{a}$ & $1.40 \mathrm{a}$ \\
\hline Significance & * & NS & NS & * & * & * \\
\hline Site & \multicolumn{3}{|c|}{ Malkerns } & \multicolumn{3}{|c|}{ Mangcongco } \\
\hline Mean & $1.83 \mathrm{~b}$ & $1.78 \mathrm{~b}$ & 1.67 & $0.82 \mathrm{a}$ & $1.69 \mathrm{a}$ & 1.64 \\
\hline Significance & * & * & * & * & * & * \\
\hline $\mathrm{CV} \%$ & 14.8 & 13.6 & 15.6 & 14.8 & 13.6 & 15.6 \\
\hline
\end{tabular}

Mean values within the same column followed by the same letter are not significantly different at $\operatorname{LSD} \mathrm{P}<0.05$.

*Significant at $\mathrm{P}<0.05 * *$ Significant at $\mathrm{P}<0.01 \mathrm{NS}=$ Not significant

\subsection{Effect on Grain Yield}

There was a significant $(\mathrm{P}<0.05)$ difference in grain yield in treatments in Malkens and Mangcongco. Malkerns's highest grain yield was attained in weeds controlled with 2,4D amine 480 at the full rate recommended by retailers at 2 $\mathrm{L} / \mathrm{ha}$ at yield of $8741 \mathrm{~kg} / \mathrm{ha}$. This treatment showed the maximum control of weeds, the ultimate reflection of this treatment appears as the highest grain yield. The lowest also with the treatment with 2,4-D Amine 480 but at the lower rate which is half the rate recommended by retailers of $1 \mathrm{~L} / \mathrm{ha}$ and was $6164 \mathrm{~kg} / \mathrm{ha}$. In Mangcongco, the highest yield was $4396 \mathrm{~kg} / \mathrm{ha}$ and the weeds were controlled using Lumax at a rate of $4 \mathrm{~L} / \mathrm{ha}$. The lowest yield was received in the treatment 
of 2,4-D Amine 480 at a rate of $4.3 \mathrm{~L} / \mathrm{ha}$ and it was 2573 $\mathrm{kg} / \mathrm{ha}$. Variation in yield between treatments have been attributed to the variation in weed control efficiency between treatments. Treatments with high yields might have significantly reduced competition for nutrients, water and solar radiation, hence the high yield.

There was a significant $(\mathrm{P}<0.05)$ difference in yield between the two sites. The mean yield for Malkerns was $7298 \mathrm{~kg} / \mathrm{ha}$ and Mangcongco with $3649 \mathrm{~kg} / \mathrm{ha}$, almost half of the yield received in Malkerns. One major factor attributable to the lower grain yield could have been the higher total amount of rainfall which led to leaching losses hence a lot of nitrogen losses. The higher yields in Malkerns are due to improved growth as consequence of effective control of weed and reduction in crop weed competition this might have enable maize crop to take up more nutrients. Higher grain yield may be due to minimum crop-weed competition throughout the crop growth period, thus enabling the crop for maximum utilisation of nutrients, moisture, light and space.

Table 9. Maize grain yield ( $\mathrm{kg} / \mathrm{ha}$ ) at harvest for all maize treatments.

\begin{tabular}{|c|c|c|}
\hline Treatments & Site & \\
\hline Herbicides & Malkerns & Mangcongco \\
\hline \multicolumn{3}{|l|}{ Interaction (Herbicide $\mathrm{x}$ rate $\mathrm{x}$ site) } \\
\hline No herbicide, control (hand hoeing) & $7001 b$ & $3031 b$ \\
\hline Bladex Plus $500 \mathrm{SC}$, at $3.6 \mathrm{~L} / \mathrm{ha}$ & $7566 \mathrm{~d}$ & $4427 d$ \\
\hline Bladex Plus $500 \mathrm{SC}$, at $2 \mathrm{~L} / \mathrm{ha}$ & $6554 a$ & $3568 \mathrm{c}$ \\
\hline Bladex Plus $500 \mathrm{SC}$, at $4 \mathrm{~L} / \mathrm{ha}$ & $7046 b$ & $4036 \mathrm{~d}$ \\
\hline Gardomil Gold, at $3.2 \mathrm{~L} / \mathrm{ha}$ & $7630 d$ & $4276 \mathrm{~d}$ \\
\hline Gardomil Gold, at $1.6 \mathrm{~L} / \mathrm{ha}$ & $7520 \mathrm{~d}$ & $3878 \mathrm{c}$ \\
\hline Gardomil Gold, at $3.2 \mathrm{~L} / \mathrm{ha}$ & $6910 b$ & $3877 \mathrm{c}$ \\
\hline No herbicide, control (hand hoeing) & $7019 b$ & $3789 \mathrm{c}$ \\
\hline Lumax, at $4 \mathrm{~L} /$ ha & $7020 b$ & $4396 d$ \\
\hline Lumax, at $1 \mathrm{~L} / \mathrm{ha}$ & $7716 \mathrm{~d}$ & $3843 c$ \\
\hline Lumax, at $2 \mathrm{~L} / \mathrm{ha}$ & $7050 \mathrm{c}$ & $3723 c$ \\
\hline No herbicide, control (hand hoeing) & $7049 b$ & $3606 c$ \\
\hline 2,4-D Amine 480 , at $4.3 \mathrm{~L} / \mathrm{ha}$ & $7271 \mathrm{c}$ & $2573 c$ \\
\hline 2,4-D Amine 480 , at $1 \mathrm{~L} / \mathrm{ha}$ & $6164 a$ & $2752 \mathrm{a}$ \\
\hline 2,4-D Amine 480 , at $2 \mathrm{~L} / \mathrm{ha}$ & $8741 \mathrm{e}$ & $2912 \mathrm{a}$ \\
\hline Significance & $*$ & $*$ \\
\hline Site & Malkerns & Mangcongco \\
\hline Mean & $7298 b$ & $3649 a$ \\
\hline Significance & $* *$ & \\
\hline $\mathrm{CV} \%$ & 20.6 & \\
\hline
\end{tabular}

Mean values within the same column followed by the same letter are not significantly different at LSD P $<0.05$.

*Significant at $\mathrm{P}<0.05 * *$ Significant at $\mathrm{P}<0.01 \mathrm{NS}=$ Not significant

\subsection{Effect on Labour Cost}

There was a significant difference in labour cost in treatments for Malkerns and Mangcongco. The range for all the hand weeding treatments in Malkerns was from 19.3 man-days/ha to 22.2 man-days/ha. Herbicide spraying however, took lesser time ranging from 3.9 to 9.3 mandays/ha. In Mangcongco the results also showed a similar trend. The hand hoeing treatments had a range from 16.2 to
21.1 man-days/ha, while spraying ranged from 4.1 to 15.9 man-days/ha. The variations in the treatments where herbicides were applied might have been due to the slope in the treatments, weed density and the fact that two people were spraying and weeding. There was no significant $(\mathrm{P}<$ 0.05) difference between the two sites. This was because, spraying and weeding was done with the same instruments by the same people.

Table 10. Labour cost (man-days/ha) of weed control in both sites.

\begin{tabular}{lll}
\hline Treatments & Site & Mangcongco \\
\hline Herbicides & Malkerns & \\
\hline Interaction (Herbicide x rate x site) & & $16.2 \mathrm{~b}$ \\
No herbicide, control (hand hoeing) & $22.2 \mathrm{~b}$ & $4.1 \mathrm{a}$ \\
Bladex Plus 500 SC, at 3.6 L/ha & $4.4 \mathrm{a}$ & $15.9 \mathrm{~b}$ \\
Bladex Plus 500 SC, at 2 L/ha & $9.3 \mathrm{a}$ & $4.9 \mathrm{a}$ \\
Bladex Plus 500 SC, at 4 L/ha & $4.5 \mathrm{a}$ & $20.5 \mathrm{~b}$ \\
No herbicide, control (hand hoeing) & $19.3 \mathrm{~b}$ & $4.6 \mathrm{a}$ \\
\hline
\end{tabular}




\begin{tabular}{lll}
\hline Treatments & Site & \\
\hline Herbicides & Malkerns & Mangcongco \\
\hline Gardomil Gold, at 1.6 L/ha & $4.4 \mathrm{a}$ & $4.4 \mathrm{a}$ \\
Gardomil Gold, at 3.2 L/ha & $4.3 \mathrm{a}$ & $4.5 \mathrm{a}$ \\
No herbicide, control (hand hoeing) & $20.7 \mathrm{~b}$ & $20.9 \mathrm{~b}$ \\
Lumax, at 4 L/ha & $4.6 \mathrm{a}$ & $4.9 \mathrm{a}$ \\
Lumax, at 1 L/ha & $10.2 \mathrm{a}$ & $10.6 \mathrm{a}$ \\
Lumax, at 2 L/ha & $10.1 \mathrm{a}$ & $10.2 \mathrm{a}$ \\
No herbicide, control (hand hoeing) & $21.1 \mathrm{~b}$ & $21.1 \mathrm{~b}$ \\
2,4-D Amine 480, at 4.3 L/ha & $4.0 \mathrm{a}$ & $4.1 \mathrm{a}$ \\
2,4-D Amine 480, at 1 L/ha & $4.9 \mathrm{a}$ & $4.9 \mathrm{a}$ \\
2,4-D Amine 480, at 2 L/ha & $4.5 \mathrm{a}$ & $4.3 \mathrm{a}$ \\
Significance & $*$ & $*$ \\
Site & Malkerns & Mangcongco \\
Mean & $9.6 \mathrm{a}$ & $9.7 \mathrm{a}$ \\
Significance & NS & \\
CV\% & 79.9 & \\
\hline
\end{tabular}

Mean values within the same column followed by the same letter are not significantly different at $\operatorname{LSD} \mathrm{P}<0.05$.

*Significant at $\mathrm{P}<0.05 * *$ Significant at $\mathrm{P}<0.01 \mathrm{NS}=$ Not significant

\section{Conclusion}

On the basis of the results obtained from the field experiments, the following conclusions were drawn:

1. The treatments controlled weeds to a varying level in the two sites. Highest efficacy of broadleaves in Malkerns was in the treatment Lumax at the rate based on the \% clay content in the soil and in Mangcongco by using of Gardomil Gold at the full rate recommended by the retailers. All herbicides are not recommended for the control of grasses in both sites at all rates as they all showed very low efficacies. Gardomil Gold seemed to be efficient in controlling sedges in both sites, at the full rate of the retailer's recommendation in Malkerns and at half the rate recommended by retailers in Mangcongco.

2. The highest grain yield in Malkerns was $8741 \mathrm{~kg} / \mathrm{ha}$ when 2,4-D Amine 480 was used, at full rate recommended by retailer's (2 L/ha). While in Mangcongco, Bladex Plus, at the rate based on the \% clay content in the soil $(4.3 \mathrm{~L} / \mathrm{ha})$ had the highest yield of $4427 \mathrm{~kg} / \mathrm{ha}$.

3. Labour cost of herbicide control was significantly $(\mathrm{P}<$ $0.01)$ higher $(71 \%)$ for manual weeding (hand hoeing) than herbicide spraying. Manual weeding (hand hoeing), which is the most predominant method of weed control in Swaziland by smallholder farmers proved to be time consuming and laborious as it took an average of 20.3 man-days/ha as compared to 5.8 man-days/ha taken to control weeds through spraying with a herbicide.

\section{References}

[1] Ahmad, R., Hassan, B. and Jabran, K. (2007). Improving crop harvest index. Ramazan. 18: 1428-1433.

[2] Babiker, M. M., Salah, A. E. and Mukhtar, M. U. (2013).
Impact of herbicides Pendimethalin, Gesaprim and their combination on weed control under maize (Zea mays L.). Journal of Applied and Industrial Sciences. 1 (5): 17-22.

[3] Baghestani, M. A., Zand, E., Soufizadeh, S., Eskandari, A., Azar, R. P., Veysi, M. and Nassirzadeh, N. (2007). Efficacy evaluation of some dual purpose herbicides to control weeds in maize (Zea mays L.). Crop Protection Journal. (26): 936942.

[4] Dlamini, S. I., Masuku, M. and Rugambisa, J. I. (2012). Technical efficiency of maize production in Swaziland: A stochastic frontier approach. African Journal of Agricultural Research. 7 (42): 5628-5636.

[5] Edje, O. T. and Ossom, E. M. (2009). Crop Science Handbook. Blue Moon Publishers, Manzini, Swaziland.

[6] Food and agricultural organisation, (2005). Food and Agricultural Organization Report, Ministry of Agriculture and Cooperatives. Government printer, Mbabane, Swaziland.

[7] Fontem, L. A. and Chikoye, D. (2012). Efficacy of herbicide formulations for weed control in maize in a humid tropical environment. Journal of Food, Agriculture \& Environment. 10 (3\&4): 1572 - 1574.86

[8] Gharineh, M. H., and Moosavi, S. (2010). Effects of intercropping (Canola-Faba Bean) on density and diversity of weeds. Journal of Notulae Scientia Biologicae. 2 (1): 109-112.

[9] Gianessi, L. and Williams A. (2011). Overlooking the obvious: the opportunity for herbicides in Africa. Outlooks on pest management. 211-215.

[10] Harding, S. S., Taylor, D. R., Jalloh, A. B., Mahmood, N., Dixon, C. A. and Johnson, S. D. (2012). Evaluation of the efficacy of different rates of herbicides on weed growth and grain yield of two rice varieties in two rice ecologies in Sierra Leone. American Journal of Experimental Agriculture. 2 (4): 607-615.

[11] Hasanuzzaman, M., Ali, M. H., Alam, M. M., Akther, M. and Alam, K. F. (2009). Evaluation of pre-emergence herbicide and hand weeding on the weed control efficiency and performance of transplanted aus rice. American-Eurasian Journal of Agronomy. 2 (3): 138-143. 
[12] Kannan, S., and Chinnagounder, C. (2013). Evaluation of Bioefficacy, weed control efficiency in herbicide resistant transgenic stacked and conventional corn hybrids (NK $603 \mathrm{x}$ TC 1507) for crop productivity. International Journal of Scientific and Research Publications. 3 (7): 1-8.

[13] Karnataka, J. (2012). Effect of herbicides on weed control and productivity of maize (Zea mays L.). Agricultural Sciences. 25 (1): (137-139).

[14] Karnataka, J. (2012). Effect of pre and post emergence herbicides on weed control in maize (Zea mays L.). Agricultural Sciences. 25 (3): (392-394).

[15] Khan, M. and Haq. U. N. (2004). Weed control in Maize (Zea mays L) with pre and post-emergence herbicides. Pakistan Journal of Weed Science Research. 10 (1-2): 39- 46.

[16] Larbi, E., Ofosu-Anim, J., Norman, J. C., Anim-Okyere, S. and Danso, F. (2013). Growth and yield of maize (Zea mays L.) in response to herbicide application in the coastal savannah eco-zone of Ghana. Net Journal of Agricultural Science. 1 (3): 81-86.

[17] Mabuza, M. L., Hendriks, S. L., Ortmann, G. F. and Sithole, M. M. (2009). The impact of food aid on maize prices and production in Swaziland. Agrekon. 48 (1): 85-105.

[18] Munsif, F., Ali, K., Khan, I., Khan, H. U. and Anwar, M. (2009). Efficacy of various herbicides against weeds and their impact on yield of maize. Pakistan Journal of weed science research. 15 (2-3): 191-198. 89.

[19] Muthamia, J. G. N., Muriithi, F., Micheni, A. N., Terry, J., Overfield, D., Kibata, G. and Mutura, J. (2001). Participatory on- farm trials on weed in smallholder farms in maize- based cropping systems. Seventh Eastern and Southern Africa Regional Maize Conference. $11^{\text {th }}-15^{\text {th }}$ February, 2001. Embu, Kenya.

[20] National Maize Corporation. (2014). National Maize Corporation (Pty) Ltd annual report 2014. http://www.nmc.co.sz/nmc\%20annual\%20report\%20201410.p df. 10.01.2015.

[21] Olorunmaiye, P. M. (2010 a). Growth and yield in maize/cassava intercrop as affected by interactions of weed control methods. Australian Journal of Crop Science. 1 (3): 106-111.

[22] Pannacci, E. and Covarelli, G. (2009). Efficacy of mesotrione used at reduced doses for post-emergence weed control in maize (Zea mays L.). Crop Protection Journal. (28): 57-61.

[23] Rajcan, I. and Swanton, C. J., (2001). Understanding maizeweed competition: resource competition, light quality and the whole plant. Field Crops Research. 71: 139-150.

[24] Salarzi, A. (2001). Effect of different herbicides on weed population and yield of maize (Zea mays L.). Pakistan Journal of Agricultural Science 38: 1-2.

[25] Shongwe, S. (2010, December 15). Weed control tips. The Times of Swaziland, $p 4$.

[26] Simmons, B. (2006). Soil properties and herbicide behaviour. Proceedings of the 2006 Indiana CCA Conference, Indianapolis, IN. University of Illinois. U.S.A.

[27] Stougaard, R. N., Shea, P. J. and Martin, A. R. (1990). Effect of soil type and $\mathrm{pH}$ on adsorption, mobility and efficacy of Imazaquin and Imazethapyr. Weed Science Journal. 38 (1): $67-73$.

[28] Svotwa, E., Jiyane, J. and Ndangana, F. (2002). Integrated weed management: A possible solution to weed problems in Zimbabwe.

http://www.appropriatetech.net/files/Integrated_Weed_Manag ement.pdf. 9.10.2014.

[29] Subhan, F., Din N., Azim A. and Shah Z. (2007). Response of maize crop to various herbicides. Pakistan Journal of Weed Science Research. 13 (1-2): 9-15. 91

[30] Syngenta (2005). Syngenta products. http://www.syngentacropprotection.com/prodender/index.aspx ?Prodld $=874 \&$ nav $=$ resources. 03.01.2015.

[31] Thobatsi, T. (2009). Growth and yield responses of maize (Zea mays L.) and cowpea (Vigna unguiculata L.) in an intercropping system. Submitted in compliance with the requirements for the degree MSc. Agric (Agronomy) in the faculty of Natural and Agricultural Sciences Department of Plant Production and Soil Science University of Pretoria. South Africa.

[32] Tollenaar, M., Aguilera, A. and Nissanka, S. P. (1997). Grain yield is reduced more by weed interference in an old than a new maize hybrid. Agronomy Journal. 89: 239- 246.

[33] Yeganehpoor, F., Salmasi, S. Z., Abedi, G., Samadiyan, F. and Beyginiya, V. (2014). Effects of cover crops and weed management on corn yield. Journal of the Saudi Society of Agricultural Sciences. 13 (1): 1-80.

[34] World Food Programme (2014). Swaziland current issues and what the World Food Programme is doing. https://www.wfp.org/countries/swaziland. 04.09.2014.

[35] Zhang J., Zheng L., Jäck O., Yan D., Zhang Z., Gerhards R. and Ni, H. (2013). Efficacy of four post-emergence herbicides applied at reduced doses on weeds in summer maize (Zea mays L.) fields in North China Plain. Crop Protection Journal. 52: $26-32$.

[36] Zimdahl, R. L. (1983). Improving chemical systems of weed control. FAO Plant Protection Bulletin. 32 (3). 